\title{
Education, religious education and religiosity of Roma children in Slovakia
}

Our research problem deals with the education of Roma children in the Slovak school system and their religiosity, which is a part of the value orientation, and specifically focuses on children involved in religious education. The development of personal religious values of Roma children has an important impact on religious education. The research focused on this problem is presented with the methodology of selected research techniques, qualified for a value orientation study in the area of religiosity and relationships. One of the main tasks of religious education is to get the child acquainted with values that are then reflected in his/her relationship with God and other people. One of the multiple factors contributing to this formation is the concept of

* Viktória Šoltésová, $\mathrm{PhD}$ has been a research assistant at the Department of Evangelical Theology and Mission, Matej Bel University, Banská Bystrica, Slovakia since 2003 and the head of the department since 2015. She is also the head of student apprenticeship there. She received a $\mathrm{PhD}$ degree in religious education in 2008. As a teacher, she studied at the South African Theological Seminary (SATS) in Tanzania, and completed an accredited distance learning course in biblical studies at the University in Johannesburg (August 2008). In 2008, she attended the Annual Meeting of the Society of Biblical Literature in Boston, USA. She published a book Religiosity, spirituality and values in religious education (2014) and many articles in the area of religiosity of Roma children and religious education. 
God. The possibilities of religious education of Roma children are limited by the problem of cross-cultural communication, which is also reflected in their potential for religious development - the development of their faith in God and communication with Him. In the process of implementation of foreign tools for researching religiosity in the Slovak conditions, it is inevitable to take into consideration not only demographical, social and religious differences but also the specific features of Slovak spiritual culture. The spiritual world of Roma in Slovakia has its own peculiarities. Understanding the cultural value systems of a particular ethnic group is a key factor in anticipating the behavior of Roma children. Many research studies have acknowledged the impact of culture and religiosity on communication across nations and its influence on ethnic minorities. This study adopted the Brief Multidimensional Measurement of Religiousness/Spirituality (BMMRS) used by Fetzer Institute in General Social Survey (GSS) 1 to examine the value orientations and religiosity (religiousness) of a total of 78 Roma respondents comprising two groups: 46 Roma children attending Evangelical religious education and 32 Roma children not attending any religious education. It initially compares religiosity and value orientation of each of the two groups and then examines the differences in specific dimensions. The most important part of the research is the correlation analysis. We are looking for the relations between religious and value orientation in both groups of Roma children. The profiles of the value orientation are based on 26 items (Brief Multidimensional Measurement of Religiousness/Spirituality) that cover a variety of dimensions (e.g. daily spiritual experiences, beliefs, forgiveness, private religious practices, religious coping, family values and social cohesion). The study revealed some value differences between the two groups and correlation coefficients that describe the degree of relationship between two variables: religiosity and some specific personal values.

\section{Education of Roma children in the Slovak school system}

The process of European integration has focused attention on the Roma issues through the adoption and monitoring of the Copenhagen criteria

1 Executive summary. The Multidimensional Measurement of Religiousness/Spirituality (MMRS) for use in health research, http://www.fetzer.org/Resources.aspx?PageID=Resources\&NavID=1 (10.05.2004). 
for EU accession. Based on these criteria, the countries of Central and Eastern Europe have built institutions and legislative mechanisms to address Roma issues. In 2001 Slovakia ratified the European Charter for Regional or Minority Languages (ECRML) - a European treaty adopted in 1992 under the auspices of the Council of Europe to protect and promote historical regional and minority languages in Europe - for the sake of the Romani language. Minorities in Slovakia have the right to be educated in their mother tongue at all levels of education (pre-school, primary, secondary and higher education, including adult one). This training should be allowed to all pupils who so wish. However, to fulfill this right, at present there are several objective obstacles. ${ }^{2}$ The main problem is the lack of preparation of the school system for education of Roma children. ${ }^{3}$ Social exclusion occurs because Roma pupils, coming from marginalized communities, often fail already in primary school, as they cannot socialize in the current system of education. The failures of Roma pupils in primary schools, as well as how and why they are sent to special schools for retarded children are the main problems. The school does not reflect the multicultural composition of society and teachers are not prepared to teach in such conditions, as pointed by D. Hanesová. ${ }^{4}$ In 1999 a draft concept of the development of education, called the Millennium Project, was formulated. It was a long-term strategy for the growth of education, which would become the basis for the EDUMIGROM ${ }^{5}$ development of education project in the next 15-20 years. Following a public debate, the concept was elaborated into the National Program of Education in the Slovak Republic, which in 2001 was approved by the Slovak government and in 2002 adopted by the National Council. ${ }^{6}$ There are some disadvantages of the program due to personal, social, cultural or economic circumstances that can hinder children's education. They are central challenges for the EU school systems. The EDUMIGROM international research project,

2 E. Kriglerová, Diskriminácia Rómov v prístupe k vzdelávaniu, http://euractiv.sk/analyzy/ rovnost-sanci/diskriminacia-romov-v-pristupe-k-vzdelavaniu/ (17.08.2016).

3 S. Rigová, M. Maczejková, Vzdelávací systém a Rómovia, in: Čačipen pal o Roma: a global report on Roma in Slovakia, ed. M. Vašečka, Bratislava 2002, pp. 695-699.

4 D. Hanesová, Sociálna a misijná práca s rómskou komunitou, Banská Bystrica 2006, p. 44 .

5 See: http://www.edumigrom.eu/about (28.11.2016).

6 Conception of development of upbringing and education in the slovak republic for the next 15-20 years: Project Millennium, http://www.cpk.sk/web/dokumenty/npvv.pdf (20.05.2015). 
focused on a comparative examination of inclusive education of ethnic minorities, showed that segregation is present throughout Europe, but the perception of the problem and solution strategies vary considerably from country to country, especially in Eastern Europe. The tendency to promote inclusive education as a part of standard education is also supported by international research, which shows that children with special educational needs are educated in the inclusive education system that allows for adequate infrastructure services and consulting, and achieves the comprehensive development of competencies and knowledge. These studies also show that the educational chances of other children in such a system are not restricted. Finally, here are provided research conclusions that inclusiveness in education helps to spread tolerance in society. ${ }^{7}$ The Slovak Republic - by adopting a number of legislative and policy documents - declared its active interest in the issue of inclusive education in the school system. With the government resolution No. 206/2008, the concept of integrated education of Roma children and youth, including secondary and higher education, was approved. In June 2009, Slovakia took over an annual rotating presidency of the Decade of the Roma Inclusion (2005-2015) international initiative. It is an unprecedented political commitment of the European governments to eliminate discrimination against Roma people and to close the unacceptable gaps between them and the rest of society.

The revision of the action plans intended for 2010, was carried forward to the following period after the parliamentary elections. The policy of the full integration of Roma by 2020 is included in the government resolution No. 1/2012, which defines solutions, principles of access and the long-term goals. The Revised National Action Plan for the Decade of the Roma Inclusion (2005-2015) was updated for the years 2011-2015 and became an action plan for the strategy of the Slovak Republic for the Roma integration by 2020, including education. According to this document, the data on the living conditions of Roma people and their discrimination in Slovakia in recent years were collected through monitoring studies carried out by European

7 J. Kontseková, C. Koštál, Desegregácia a inklúzia vo vzdelávaní sociálne znevýhodnených žiakov v európskych školských systémoch: výzva pre Slovensko, in: Odpovede na otázky (de) segregácie rómskych žiakov vo vzdelávacom systéme na Slovensku, ed. V. Rafael, Bratislava 2011, pp. 19-22; http://www.edumigrom.eu/sites/default/files/field_attachment/page/node-23788/ edumigromfinal-study.pdf (10.04.2015). 
institutions and through specialized sociological surveys conducted in the Roma areas. Among the priorities of the strategy for the inclusion of Roma people by 2020 , a prominent place is held by education. ${ }^{8}$

After the previous public debate in 2014, the Slovak Ministry of Education published a report on the state of education. It formulated key recommendations for the application of inclusion principles to education and training:

- to monitor, evaluate and publish segregation/desegregation practices of the founders and directors of kindergartens, primary schools and school facilities; to monitor their impact on the success, attendance, socializing, etc. of children and pupils from the socially disadvantaged environment,

- to develop a methodology for monitoring and controlling the segregation practices; to assist in the desegregation of children and pupils coming from socially disadvantaged backgrounds. ${ }^{9}$

A positive step in education of Roma children is - present in some classes system of their assistants, as well as "zero classes" which prepare children to enter school. Preschool programs are important bridges preparing children to the classroom environment and to overcome language differences. Thus, high proportions of Roma children are still being channeled into special schools. ${ }^{10}$ According to the Institute of Information and Prognosis of Education and Statistics, the number of Roma children in kindergartens decreased after the 1989 revolution to $0.7 \%$. This low percentage significantly contributed to the serious problem of Roma schoolchildren in their first year of primary school. Following the development of the "zero classes" project and its approval by the Ministry of Education, an experiment was conducted in selected primary schools in eastern Slovakia with a high concentration of Roma children. Based on the results of the experiment, it can be concluded that the effectiveness of preparatory classes was confirmed in the areas of acceleration of writing skills, verbal expression and vocabulary. ${ }^{11}$ Generally, children from zero classes had a more positive attitude to school and the school environment. Since the zero grade curriculum is often created by dividing the curriculum of the

8 http://www.rokovania.sk/Rokovanie.aspx/BodRokovaniaDetail?idMaterial=20646 (20.05.2015).

9 https://www.minedu.sk/sprava-o-stave-skolstva-na-slovensku/ (08.04.2015).

10 I. Radičová, Hic Sunt Romales, Bratislava 2001, p. 59.

11 S. Rigová, M. Maczejková, Vzdelávací systém a Rómovia..., pp. 709-710. 
first year into two years (allowing for a slower pace of teaching), zero grade pupils usually form a homogeneous class in the first year and then continue their education in the same group throughout primary school. Nevertheless, according to the statistics, the difference in the formal educational level of the (especially marginalized) Roma population, compared to the majority population, is abysmal. The most important problem of Roma schoolchildren is a language barrier, so we look more closely at the current situation of education in the Romani language.

Many non-governmental organizations (NGOs) participate in solving Roma problems. They deal with education in Roma communities, e.g. by means of supporting the idea of Roma assistant teachers in the first grade of primary schools. They also handle the intercultural communication and education in the area of human rights. The cooperation between schools, NGOs and Churches is developing. An example of this is the strategy of the social and economic integration of Roma communities in the County of Banska Bystrica for 2007-2013. Many workers and volunteers from the field of education, employment, healthy living, housing, infrastructure, social relations etc. participated in drafting the strategy as well as in its implementation. The concept follows the structure of the National Action Plan of the Slovak Republic Regarding the Decade of the Roma Inclusion (2005-2015), which was adopted by the Slovak government.

\section{The issue of the Romani language in education}

The legal situation of Roma people was discussed in different member states of the European Union. Those countries which recognized the Romani as a national minority should be contrasted with those that haven't done so. The Romani language represents one of the most important elements forming the sense of identity of the Roma minority. One barrier to implement the Romani language is that the official figures for people who identified themselves as Roma in the last census differs from the real size of the Roma population. Another is that the Romani language exists in a number of dialects in Slovakia, it is codified, but not spoken by all Roma people. It makes its usage complicated. Problems exist in the implementation of this right for Roma children in schooling. There is also a lack of teachers and textbooks. 
In 2003 the Secretariat of the Plenipotentiary of Government of the Slovak Republic for Roma Communities has tasked a group of experts to establish a commission for re-codifying of the Romani language and the work was completed in 2008. The re-codified Romani language can serve as an effective tool in the implementation of the project of teachers' assistants at the level of primary education, and at the same time can contribute to preservation and stimulate a more dynamic development of Roma culture. The Romani language and its usage are also grounded in the applicable legislation and international conventions ratified by the Slovak Republic. But in the majority population, within the state administration, as well as in expert circles, there are mixed reactions to the usage of the Romani language. It can stimulate a more dynamic development of Roma culture.

The Roma minority has a national minority status with the right to education in the Romani language. Currently, there are several books about Romani grammar as well as some Romani textbooks. There are few schools teaching the written form of the Romani language as a school subject. However there is no pedagogical faculty in Slovakia where students might graduate as Romani teachers. Also, there are no textbooks that use Romani as the language of instruction for other compulsory subjects (such as science, history, etc.). These are the main official reasons why there are no schools where Romani is the language of instruction. ${ }^{12}$ Dialects of the Romani language are influenced by the languages of the majority in a variety of local regions. This demonstrates language flexibility of Roma people. But Roma culture is not fixed on special Roma cultural institutions. ${ }^{13}$ It is difficult for some Roma adults to understand a similar but not identical dialect of the Romani language. In 2008 the standardization of the Romani language was declared in Slovakia through signing a document in the National Council. The Romani language standardization is the act which laid the legislative foundations for the creation of valuable conditions for education in the Romani language, including the preparation of teachers teaching the Romani language or in the Romani language, the use of the Romani language in public, and cultural life of ethnic minorities in terms of the application

12 T. Gažovičová, The Romani language in the Slovak educational system, "Human Affairs" (2012) No. 22, pp. 510-523.

13 Z. Uherek, K. A. Novák, Etnická identita Romů, in: Čačipen pal o Roma..., pp. 93-111. 
of Law No. Collection of Laws 184/1999 dated 10 July 1999 on the use of Minority Languages and the European Charter for Regional or Minority Languages. ${ }^{14}$ In 2010 the State Pedagogical Institute published the results of Experimental Verification of the Effectiveness of the Curriculum of the Romani Language and Literature at Primary School and Second School Level. The results of the verification include the content and the output standards in these subjects, and the classification of the Romani language and literature as optional GCE subjects. ${ }^{15} \mathrm{~A}$ persistent problem remains a lack of qualified teachers of those subjects and a lack of textbooks and materials. In Slovakia, it is also a lack of teachers who would be able to teach the Romani language or teach in the Romani language. In this area, some changes happen successively, which might improve the situation. In some research done in Slovakia, insufficient interest in education in this language was found on the part of the Roma population. This phenomenon is the result of the symbolic exclusion of Roma people and many years of the efforts of the socialist regime of their cultural and social assimilation. ${ }^{16}$ As part of the project of the experimental verification of the Romani language, several primary and secondary schools have been set up, in which currently the Romani language, culture and history are taught. The experiences of this project could in future serve as a model for education in the Romani language. Slovakia implemented a number of non-governmental projects that serve as a positive model of resolving the issue of unequal access of Roma children to education. Many of these projects (for example, preparatory classes and assistant teachers) are already notorious and even included in the current legislation such as country-wide projects. Alternative education for Roma pupils were carried out during 1999/2000 and 2000/2001 school years and started with two projects named "Acceleration of Roma Pupil Success at Schools" and "Reintegration of Roma Pupils from the Socially and Educationally Handicapped Environments of Special Primary Schools into the Majority Population." The most significant international project was the one entitled "Step by Step," implemented in many countries with a high Roma population, as well as in Slovakia, where it received a positive

14 http://www.mpc-edu.sk/library/files/romsky_jazyk.pdf (05.02.2012).

15 http://statpedu.sk (20.05.2015).

16 E. Šotolová, Vzdělávání Romů, Praha 2000. 
feedback. This project was aimed at integrating children coming from disadvantaged backgrounds and special schools into the standard primary schools. In October 1998, a founding coalition of Step by Step NGOs voted to establish the International Step by Step Association (ISSA), a formal regional network that would support the national Step by Step NGOs, and later other organizations, while also providing a voice for professionals promoting progressive approaches to early childhood education. ${ }^{17}$ ISSA and its local partners are supporters of intensive cooperation with parents and the community, which is promoted through teaching assistants who should be members of ethnic minorities. The same project also works in Slovakia within university education of qualified teacher assistants.

In Slovakia, there is still a lack of qualified teachers who would be able or willing to work with Roma children. Similarly, teachers of religious education lacking the language skills. If an opportunity was established for student teachers to volunteer in the education of Roma children with the help of adequate textbooks and a multicultural approach, it is very likely that the situation of the preparedness of Roma children for education could significantly improve. Since the Roma people, as a national minority in Slovakia, have the right to be educated in their language, it is necessary to develop mechanisms that would make it possible. In 2014, the Government Office of the Slovak Republic published Report on implementation of European Charter of Regional or Minority Languages in Slovak Republic. The amendment to Act No. 184/1999 Collection of Laws on the use of minority languages, as amended in 2011, supports the ability to communicate in a minority language in municipalities that do not reach the $20 \%$ limit for oral communication. It also lowered - after two consecutive censuses of population - the threshold for the use of minority languages to $15 \%$. The Committee of Experts in article 8 urges the Slovak authorities to adopt a structured approach and interact with people speaking the Roma language, in several cases to introduce the teaching of the Romani language for Roma children. The national project "Inclusive model of education in pre-primary levels of education" (MRK II) wants to achieve the integration of children, coming from marginalized Roma communities, with kindergartens, and the active education of parents

17 Step-by-Step: an alternative methodology handbook for the first grade of primary school, p. 109; http://www.issa.nl/content/our-organisation (22.10.2014). 
to improve the children's readiness to enter the primary stage of schooling. ${ }^{18}$ School legislation allows for primary and secondary schools teaching in the Romani language through the school curriculum (the optional disposable hours). For the school that have expressed interest in the subject, there are educational standards for the Romani language and literature (for primary, lower secondary and upper secondary education), available on the website of the State Pedagogical Institute. A commission for courses of the Romani language and literature, and Roma culture is established at the National Institute for Education. The commission is engaged in upgrading educational standards and offers alternative teaching options of the Romani language in schools.

\section{Religious education of Roma children}

According to the ethnographical research, the ethnicity of the Roma minority in the Slovak Republic is interconnected with other categories. We can describe it as a multi-layered identity. Ethnicity is combined with the categories of citizenship, Roma culture and denominational identity. The research in Slovakia has also revealed "multi-layered public religiosity." It is a combination of older "pre-Christian" and new Christian concepts and ideas. ${ }^{19}$ These concepts are superstitions, e.g. based on signs in dreams and their interpretation. Worldly and posthumous punishments are in contradiction; the reason for God's punishment is breaking an oath. Sanctions, ceremonials and an oath of loyalty are part of the culture. Religiosity is one of the most important parts of the Roma social and socio-cultural development which proceeds slower in traditional Roma communities than in the majority of the population. We can see components of Roma spiritual culture in archaic forms until today. The first research of Roma religiosity in our area discovered a typical pattern of the magic practices covered up by the formal Christianity. ${ }^{20}$

18 Report on implementation of European Charter of Regional or Minority Languages in Slovak Republic, 2014, pp. 12-15, 79-84.

19 Boh všetko vidí. Duchovný svet Rómov na Slovensku, eds. M. Kováč, A. B. Mann, Bratislava 2003, pp. 17-35, 124.

20 M. Jakoubek, Romové-Konec (ne)jednoho mýtu. Tractatus culturo(mo)logicus, Praha 2004, p. 179. 
Roma spiritual culture developed in dependency on the social situation of the Roma people. We can find more symbols of the traditional culture in the country. The growing secularization of society makes religious education more difficult. Some European countries maintain a state-supported religion, usually either Roman Catholicism, Lutheranism, or Orthodox Christianity. Religious education is taught in special classes of public schools. Many families put their children into religious schools, most often schools founded by the Roman Catholic Church. Slovakia has a long history of almost even division between Roman Catholics and Protestants, and has an arrangement under which religious bodies oversee the training of mainline Catholic and Protestant religious education teachers who teach religion in public schools. The state also subsidizes religious schools. Today religious, moral and spiritual education has become an important issue. This is the context in which a worldwide revival of interest in spiritual, moral and religious education takes place. The principles of cross-cultural communication are to be observed in cross-cultural religious education in schools and churches. In view of the location of primary schools, religious education also focuses on the education of Roma children while religious education is a partially optional subject. It is important for catechists to understand the image of God among Roma children. Researchers (Kováć, Mann) discovered that Roma children have the image of God based on specific ideas. In the studied areas, prayers said to God by Roma children are more or less individual and not governed by the liturgical patterns. Gypsies in the village of Borka have a personal and familiar relationship with God (o Del), which is often called the little God (Deloro). They perceive God in a human form in the person of Jesus (a young man with light brown hair and blue eyes) or like a glare or light. Research focused on the faith of Roma children was conducted in the village of Lomnicka, using a questionnaire and follow-up informal discussions about the faith in God. Traditionally, people pray their own evening prayer in which they are also talking about all day experiences. Children said that they do not fear God. Their idea of God is that he is a good and just person. "He is like a father whom we are confessing our sin and who forgives us, because He is merciful." Children say that they wish to see Jesus and ask him in the Romani language about a revelation of his person: "Deloro av ke mande, kamav tut te dikhel" ("God, come to me, I love you, give me a revelation of Yourself"). Children usually kneel when pray. Some pray in the Romani language and 
know the Ten Commandments by heart. The Romani's faith in God who "is living among them" is generally known. In the village of Telgart some said: "Baby Jesus lives among us..." They say that God is invisible and is a spirit. More dedicated ones have a specific concept of God: "God is probably a man, but nobody has seen Him, God must be big and have big hands and eyes to see the whole world." Others say that "Jesus is the judge who sits on a chair in the sky and all around him are angels." An important need of the Roma people is to be near God ("God must be with us everywhere at every step").21 It is actually more important that the idea of God's image.

Our research is focused on verifying elements related to the internalization of religiosity by Roma children and measuring other values (such as forgiveness to others and to oneself, or willingness to help others). We have found out that the more intrinsically religious Roma children are more socially-oriented, their scores are higher in the dimensions of friendliness and forgiveness. ${ }^{22}$ This research also indicated a positive correlation between faith in God and pro-social sentiments declared in an effort to help people suffer less and feel better. Roma children who were attending a systematic catechetical course/religious education expressed a deeper level of desire to be nearer God in a closer relationship with the Lord Jesus. Noema Brádňanská and Dana Hanesová ${ }^{23}$ described children's images of God. They found out that most children were able to articulate their personal ideas of God. Their images of God were influenced by a) their family background (Christian/nonChristian; b) the school background (the influence of religious education/ ethics); c) the Church background; and d) the societal context (for example their drawings of heaven with angels clearly reminded some computer game characters). In 2011-2013, Dana Hanesová conducted several research studies among approx. 150 primary school children. One of them showed that only $1 \%-2 \%$ of children were able to articulate the Christian meaning of Easter or Christmas or even to explain the symbols of these festivals. It seems to

21 Boh všetko vidí..., pp. 61, 75, 133-134.

22 V. Šoltésová, Die Religiosität der Romakinder in der Slowakei, in: Gott hat das Auftrag gegeben: mit Kindern über Schöpfung und Weltentstehung nachdenken Herausgegeben, Hrsg. Ch. Kalloch, M. Schreiner, Stuttgart 2012, pp. 185-197.

23 N. Brádňanská Ondrášek, D. Hanesová, Theologizing with children: research on children's images of God in Slovakia, in: Symmetrical communication? Philosophy and theology in classrooms across Europe, eds. F. Kraft, H. Roose, G. Büttner, Loccum 2011, pp. 75-84. 
confirm the presumption that children's parents hesitate to put too much religious pressure on them. In some Western societies the majority of parents gradually decide not to bring their child to church because they are afraid of "too direct involvement" in their children's religious decisions.

For religious education, it is necessary to have effective tools prepared for this task. Written materials in the Romani language should help in this process. The Lutheran Church prepared a bilingual songbook for young people in the Romani and Slovak languages - Songs of new life. In the world without God, an originally Slovak novel by Kristina Royova, was published in the Romani language in 5,000 copies. The second edition of the novel was supplemented with the Lord's Prayer, the Ten Commandments and a short glossary in three Romani dialects. In 2013, translators from the Word for the World organization completed the translation of the New Testament into the North-Central dialect of the Romani language (spoken in Eastern Slovakia) and are preparing the translation of the Old Testament into the same dialect.

\section{Religiosity of Roma children of Slovakia}

Our research analyses empirical data collected in primary schools in different regions of Slovakia. The schools were selected based on whether Roma children attend religious education of not. In the preparatory phase, we asked Roma children who attend religious education the following questions: "Is it possible to notice a positive attitude to the value of God and a personal relationship with Him?"; "Which elements of religious orientation of Roma children have positive values?"; "Is there a relationship between the religiosity of Roma children and the selection of specific life values?". We have formulated five main hypotheses. For their statistical verification, we used two selections of F-test for variance and two selections of t-test (both with the significance level $\alpha=0.05$ ) and Kendall correlation coefficient. Some of our findings correspond to the partial results of other studies. In one example we will quote a part of one of the hypothesis:

There is little to almost strong relationship between the values in matters of faith in God (question 7 "I believe in a God who watches over me.") and personal and social responsibility as defined in question 8: "I feel a deep sense of responsibility for reducing pain and suffering in the world." The 
calculation of correlations between responses to the scaled questions 7 and 8 showed that there is a relation between them, which confirmed our hypothesis. Among respondents who attend religious education, there is a medium level of correlation (Kendall correlation coefficient 0.325 ). In the group of respondents who do not attend religious education, we found a weak relation between the examined variables. We can say that we found differences between the two groups of respondents on the level of daily spiritual experiences. In the first question about the perception of God's presence, there were significant differences between the two main groups of respondents. The result of t-test is significant -3.78 , so we found that in our selection there was a significant difference between Roma children attending Evangelical catechesis and those who don't. In the group of children who attend catechesis, we assumed a correlation between acceptance of the life as the part of a larger spiritual force (question 17) and friendly cooperation with God (question 18: "I work together with God as a partner"). In this case, we found that there is a correlation among the variables in our selection. The results in our selection showed that children who believe that God directs their lives, can at the same time communicate with Him as a friend. Friendly communication with God is an important part of the internalization of religiosity. In terms of the selection, it was found that belief in God correlates with the declared effort to do whatever possible to be a better person and to help people suffer less. We found a higher level of connection in the group of respondents who attend catechesis. On average, we found a reciprocal relationship between faith in God and forgiving oneself in the group of Roma children attending Evangelical catechesis. There was no evidence, however, of the relation between faith in God and forgiving those who hurt me. When interpreting the negative relationship, it would not be correct to refer to the young age of the selected groups of children. Therefore, we concluded that even if we accept the level of cognitive development, the willingness of forgiving among the selected Roma children is lower than expected. We noted, however, a link between the values of forgiving others and knowing God's forgiveness ("I know that God forgives me"). Thus, the children confirmed their willingness to help others, but were not willing to forgive them. In our opinion, this result may be influenced by several factors, which suggests a lower level of social conscience and social development. Likewise, they may have been mediated by the level of understanding relationships by their 
parents, or religious education teachers. In our research, in the group of children attending religious education, we found a higher level of feeling close to God and the desire to have a closer relationship with Jesus Christ. The results showed a significant association between whether an individual is trying to forgive themselves and their awareness of God's forgiveness (which may be formed under the influence of catechesis). As the strongest relation, I can mention a positive correlation between the desire to give God control of personal life and the experience of friendly communication with Him (the group of Roma children attending Evangelical catechesis). The declared religiosity in our group of Roma children really correlates with religious behavior. The results of the analysis of the confirmatory factor brought interesting data. Among respondents attending religious education, a single factor was found, which we called internal religiosity. Among respondents who do not attend religious education, elements related to internal and external religiosity overlap to the saturation of one factor. Overall, we can say that at a higher level of faith in God, positive signs of internal religiosity dominate in our group of children. We found that the subjects scored high was the confidence that their lives are controlled by God, they tend to be open in their personal communication with the transcendent God and their communication with Him is perceived as friendly. Furthermore, children claiming that they forgive others and themselves bad things, were marked as having strong faith in God (the level of internal religiosity). We examined the relationship between several variables belonging to the religiosity of Roma children. The findings concerning a lack of correlation in the affective areas of the religiosity of children attending religious education demonstrate the need for change of approach in catechesis. The low correlation between feeling close to God ("I feel God's presence") and the joy of faith in Jesus also show the lack of internalization of religiosity. The obtained results also contributed to intercultural research of religiosity. Similarly, we did not find any relation between children's faith in God's closeness ("I believe in a God who watches over me"), and the willingness to forgive those who wronged them ("I have forgiven those who hurt me"). We think that these partial results can be guidelines for catechetical work of Evangelical Churches in Roma communities in Slovakia. In particular, we can see the importance of the research and its results that can help us draw up documents for catechesis of Evangelical Churches. When completing catechetical materials for children 
of all ages, necessary for religious education in schools, we should focus on the specifics of the catechesis of Roma children. The results can be applied to the educational catechetical practice. We can see their practical significance in their future application to the preparation of catechists. We believe that our findings may encourage others to reflect on the efficiency of the delivery of the religious content and Christian values in the process of development of Roma children's religiosity. The content of religious education is to create relationships with oneself and with other people. The role of religious education is to present value education while reflecting on the level of the child's cognitive, emotional and social development. The results of our research suggest that in the process of religious education of Roma children, we should take into consideration their level of internal religiosity and personal relationship with God.

Religious education in Slovakia is a partially optional subject since there is a compulsory choice to be made by parents/children between religious education and secular ethics. In Slovakia, similarly to the majority of EU countries $^{24}$, the legislation on religious education allows for "denominational" approach in all kinds of schools - state, private and religious. This means that religious education teachers not only teach children about religion/religions, but can also lead them into their own specific Christian faith. In Slovakia, all of the eighteen religious communities or denominations have the right to write their own curriculum, have it approved by the Ministry of Education and implement in school. Currently, only five Churches are teaching their religious education: the Roman Catholic, the Greek Catholic, the Orthodox, the Lutheran and the Reformed Church. The purpose of religious education in all Christian denominations in Slovakia is to help parents in their effort to lead children towards moral and spiritual maturity and internalized faith. This is similar to the purpose of parish catechesis. But the content, and especially the teaching methods, have to be adjusted to the specific school context. In the process of religious education, an individual learns behavioral norms that substantially regulate not only religious but also other social actions. The

24 D. Hanesová, Náboženská výchova v Európskej únii, Banská Bystrica 2006. 
family has a vital importance in religious socialization, and religion plays a role in the development of the child's deep religious attitudes. Developing children's religiosity is the main objective of religious education, which is conditional on the knowledge of God and the development of the child's emotional relationship with Him. Roma children have the concept of God based on specific ideas.

This study adopted Brief Multidimensional Measurement of Religiousness/Spirituality (BMMRS) used in the last years by Fetzer Institute in General Social Survey (GSS) to examine religiosity of a total of 78 Roma respondents, comprising two groups: 46 Roma attending Christian catechesis and 32 Roma not going to church. The study revealed some valuable differences between the two groups and correlation coefficients that describe the degree of relation between two variables: personal religiosity and some specific personal values. The research also indicated a positive correlation between faith in God and pro-social sentiments declared in an effort to help people suffer less and feel better. We focused on verifying the elements related to internal religiosity and measuring other values (such as forgiveness, willingness to help) on a smaller group of respondents. In our research, we focused on children's daily spiritual experiences, their image of God and experience of a relationship with Jesus Christ. We found a connection between religiosity and socially-oriented values. In the Polish environment, which is similar to Slovak religiosity, R. Kosek investigated the relationship between dimensions of religiosity and the five-factor model of personality. He found that the internal religiosity is in the significantly positive relation to friendliness/ kindness and conscientiousness. ${ }^{25}$ These results partly correspond to the observed positive correlation between faith in God and prosocial feeling ("I feel a deep sense of responsibility for reducing pain and suffering in the world"). Openness to the experience of spiritually-oriented individuals is also reflected in the experience of relationship with God. The existence of a personal relationship with Him was declared in our study by children attending religious education. In our research, in the group of Roma children who had an experience of religious education in church, we found a higher level of feeling close to God and the desire for a deeper relationship with

25 R. B. Kosek, Adaptation of the big five as a hermeneutic instrument for religious constructs, "Personality and Individual Differences"1999 No. 27, pp. 229-237. 
Him. We found that children who scored high in confidence that their lives are controlled by God, tend to be open in the personal communication with God. Furthermore, children who scored high in claiming that they had forgiven themselves for things that they had done wrong, had a high level of faith in God (high level of internal religiosity). The results show a significant direct association between whether a child is trying to forgive themselves and their consciousness of God's forgiveness (which can be formed under the influence of catechesis). The declared religiosity in our group really correlates to religious behavior. Roma children with higher levels of belief in God show positive indications of internal religiosity.

By working on the research, we broadened our knowledge of the complex issue of religiosity in the development of the child's personality. We would like to use the results of the research in formulating new targets for religious education of Roma children. An important element is the need for the preparation of materials for their catechesis. The research findings have implications for religious behavior and education. The employment of the same measures in another group of respondents would increase our understanding of the religious imagination of Roma children in Slovakia. Future research is needed to examine other areas of beliefs and the concept of God among Roma children, formed in the process of religious education.

\section{Bibliography}

Boh všetko vidí. Duchovný svet Rómov na Slovensku, eds. M. Kováč, A. B. Mann, Bratislava 2003.

Brádňanská Ondrášek N., Hanesová D., Theologizing with children: research on children's images of God in Slovakia, in: Symmetrical communication? Philosophy and theology in classrooms across Europe, eds. F. Kraft, H. Roose, G. Büttner, Loccum 2011, pp. 75-84.

Conception of development of upbringing and education in the Slovak Republic for the next 15-20 years: Project Millennium, http://www.cpk.sk/web/dokumenty/npvv.pdf (20.05.2015).

Executive summary. The Multidimensional Measurement of Religiousness/Spirituality (MMRS) for use in health research, http://www.fetzer.org/Resources. aspx?PageID=Resources\&NavID=1 (10.05.2004). 
Gažovičová T., The Romani language in the Slovak educational system, "Human Affairs" (2012) No. 22, pp. 510-523.

Hanesová D., Náboženská výchova v Európskej únii, Banská Bystrica 2006.

Hanesová D., Sociálna a misijná práca s rómskou komunitou, Banská Bystrica 2006.

Jakoubek M., Romové - Konec (ne)jednoho mýtu. Tractatus culturo(mo)logicus, Praha 2004.

Kosek R. B., Adaptation of the big five as a hermeneutic instrument for religious constructs, "Personality and Individual Differences"1999 No. 27, pp. 229-237.

Kontseková J., Koštál C., Desegregácia a inklúzia vo vzdelávaní sociálne znevýhodnených žiakov v európskych školských systémoch: výzva pre Slovensko, in: Odpovede na otázky (de)segregácie rómskych žiakov vo vzdelávacom systéme na Slovensku, ed. V. Rafael, Bratislava 2011, pp. 19-22.

Kriglerová E., Diskriminácia Rómov v prístupe $k$ vzdelávaniu, http://euractiv. sk/analyzy/rovnost-sanci/diskriminacia-romov-v-pristupe-k-vzdelavaniu/ (17.08.2016).

Radičová I., Hic sunt Romales, Bratislava 2001.

Rigová S., Maczejková M., Vzdelávací systém a Rómovia, in: Čačipen pal o Roma: a global report on Roma in Slovakia, ed. M. Vašečka, Bratislava 2002, pp. 695-699.

Step-by-Step: an alternative methodology handbook for the first grade of primary school, http://www.issa.nl/content/our-organisation (22.10.2014).

Uherek Z., Novák K. A., Etnická identita Romů, in: Čačipen pal o Roma: a global report on Roma in Slovakia, ed. M. Vašečka, Bratislava 2002, pp. 93-111. Šoltésová V., Die Religiosität der Romakinder in der Slowakei, in: Gott hat das Auftrag gegeben: mit Kindern über Schöpfung und Weltentstehung nachdenken Herausgegeben, Hrsg. Ch. Kalloch, M. Schreiner, Stuttgart 2012, pp. 185-197. Šotolová E., Vzdělávání Romů, Praha 2000.

http://www.edumigrom.eu/sites/default/files/field_attachment/page/node-23788/ edumigromfinal-study.pdf (10.04.2015).

http://www.issa.nl/content/our-organisation (22.10.2014).

https://www.minedu.sk/sprava-o-stave-skolstva-na-slovensku/ (08.04.2015).

http://www.mpc-edu.sk/library/files/romsky_jazyk.pdf. (05.02.2012).

http://www.rokovania.sk/Rokovanie.aspx/BodRokovaniaDetail?idMaterial= 20646 (20.05.2015).

http://statpedu.sk (20.05.2015). 